Original Research Paper

\title{
Coaching Online Pembelajaran Jarak Jauh Bagi Guru Sekolah Dasar
}

\author{
Qurnia Indah Permata Sari ${ }^{1 *}$ \\ ${ }^{I}$ Fakultas Ilmu Sosial dan Ilmu Politik, Universitas Brawijaya, Malang, Indonesia
}

https://doi.org/10.29303/jpmpi.v3i2.595

Sitasi: Sari, Q. I. P. (2021). Coaching Online Pembelajaran Jarak Jauh Bagi Guru Sekolah Dasar. Jurnal Pengabdian Magister Pendidikan IPA, 4(1)

\author{
Article history \\ Received: 02 Desember 2020 \\ Revised: 29 Desember 2020 \\ Accepted: 22 Januari 2021 \\ *Corresponding Author: Qurnia Indah \\ Permata Sari, Fakultas Ilmu Sosial dan \\ Ilmu Politik, Universitas Brawijaya, \\ Malang, Indonesia. \\ Email: \\ qurniaindahpermatasari@gmail.com
}

\begin{abstract}
Pemerintah melalui Kementerian Pendidikan dan Kebudayaan (Kemendikbud) memberlakukan Pendidikan Jarak Jauh (PJJ) untuk mencegah semakin bertambahnya penularan virus di sekolah. Ketimpangan akses internet dan masalah Sumber Daya Manusia (SDM) menjadi permasalahan utama pada pemberlakuan Pendidikan Jarak Jauh (PJJ). Oleh karena itu diperlukan pelatihan online Pembelajaran Jarak Jauh (PJJ) bagi Guru Sekolah Dasar untuk mempelancar Kegiatan Belajar Mengajar (KBM). Tujuan penulisan jurnal ini ialah untuk menjelaskan peran generasi muda dalam membantu masyarakat yang terdampak dari pandemi Covid19 khususnya dari sektor pendidikan yaitu guru sekolah dasar. Manfaat dari penulisan artikel ini adalah untuk memberikan inspirasi bagi insan akademisi dalam membantu memecahkan masalah yang dihadapi oleh masyarakat terutama saat pandemi covid-19.
\end{abstract}

Keywords: Pendidikan jarak jauh; Pelatihan online; Covid-19.

Perubahan pola pembelajaran yang revolusioner sebagai dampak adanya pandemi Covid-19 membuat guru sekolah dasar kesulitan dalam menyesuaikan pembelajaran. Dalam rangka mempersiapkan sistem pembelajaran jarak jauh tidak hanya sekedar infrastruktur yang dibutuhkan, namun pengetahuan sumber daya manusia juga diperlukan. Maka dari itu, sudah menjadi tanggung jawab bagi akademisi untuk sekolah dasar berbagi pengetahuan dengan guru agar bersama-sama menghadapi imbas dari adanya covid-19.

Terdorong oleh situasi tersebut, maka Pusat Studi Pesantren dan Pemberdayaan Masyarakat (PSP2M) Universitas Brawijaya Malang berupaya untuk terlibat dalam pemberdayaan masyarakat dalam menghadapi dampak dari covid-19 dengan menyelenggarakan program dengan tema "Participatory Action for Covid-19 Impact" (PeCI).
Pembelajaran Jarak Jauh (PJJ) bagi Guru Sekolah Dasar untuk mempelancar Kegiatan Belajar Mengajar (KBM). 
Target dari kegiatan yang dilakukan oleh maka Pusat Studi Pesantren dan Pemberdayaan Masyarakat (PSP2M) ini adalah peningkatan kompentensi sumber daya manusia dalam menyelenggarakan pembelajaran daring. Salah satu Tim yang berfokus pada bidang pendidikan adalah Tim Transformasi Pendidikan.

Tim Transformasi Pendidikan menyelenggarakan dua acara besar untuk membantu guru dalam mempelancar Pembelajaran Jarak Jauh, acara tersebut diantaranya sebagai berikut, Pertama, Rembug Online untuk memetakan permasalahan Guru Sekolah Dasar dalam pembelajaran daring serta saling berbagi antar sesama guru untuk menyelesaikan permasalahan pembelajaran daring, Kedua, Coaching Online yang dilakukan oleh mahasiswa yang tergabung dalam Tim Transformasi Pendidikan untuk memfasilitasi Guru Sekolah Dasar dalam membuat materi pembelajaran untuk menunjang Kegiatan Belajar Mengajar (KBM).

\section{Metode}

Metode yang digunakan pada kegiatan Pengabdian kepada masyarakat ini adalah metode Participatory Action Research. Menurut Kamber (2000), Participatory Action Research (PAR) adalah metode yang menekankan pada praktik, bertujuan ke arah peningkatan, suatu proses siklus, diikuti oleh penemuan yang sistematis, bersifat partisipatif dan mendorong masyarakat untuk berpartisipasi dalam kegiatan (Kamber, 2000). Sesuai dengan konsep Participatory Action Research (PAR) tersebut, kegiatan pengabdian ini melihat masyarakat atau kelompok sasaran sebagai insider atau subjek bukan sebagai outsider atau objek kegiatan (Adimiharja \& Hikmat, 2003). Pendampingan kepada kelompok sasaran dilakukan melalui aplikasi zoom yang dilaksanakan pada tanggal 22 Juni 2020-27 Juni 2020.

\section{Hasil dan Pembahasan}

Coaching Online merupakan salah satu solusi untuk membantu guru dalam menggunakan beberapa aplikasi yang bisa digunakan untuk memperlancar proses kegiatan belajar mengajar dalam masa pandemi covid-19. Coaching Online dilaksanakan pada tanggal 22 Juni 2020-27 Juni 2020 dengan menggunakan Zoom. Coaching Online merupakan kegiatan lanjutan dari Rembug Online yang diselenggarakan pada tanggal 15 Juni 2020. Rembug Online tersebut mengangkat tema "Pemetaan Masalah Pembelajaran yang dihadapi Guru Sekolah Dasar di saat Pandemi Covid-19”.

Rembug Online yang diselenggarakan tersebut bertujuan untuk memetakan permasalahan pembelajaran selama masa pandemi Covid-19 serta mencari solusi dari permasalahan pembelajaran daring tersebut. Rembug Online tersebut diikuti oleh 77 peserta dengan latar belakang guru sekolah dasar, ketua gugus serta kepala sekolah yang berasal dari seluruh Indonesia. Adapun pemantik dalam acara ini adalah Muhammad Arif Kamal, STP, M.Si, Rachmad Gustomy, S.IP., M.IP, dan Trisna Andarwulan, S.S., M.Pd.

Salah satu rekomendasi yang didapatkan dari acara Rembug Online tersebut adalah pelatihan bagi guru dalam rangka mengoperasikan aplikasi yang digunakan dalam pembelajaran daring di masa pandemi covid-19. Oleh karena itu, berawal dari rekomendasi tersebut Tim Transformasi Pendidikan kemudian menyelenggarakan Coaching Online dalam rangka memfasilitasi guru sekolah dasar untuk mempelajari aplikasi yang terkait dengan pembelajaran daring.

Coaching Online tersebut diikuti oleh 17 orang peserta yang mengikuti acara dari awal hingga akhir. Narasumber dalam acara Coaching online tersebut ialah mahasiswa yang menjadi volunteer dalam acara pengabdian masyarakat yang diselenggarakan oleh Pusat Studi Pesantren dan Pemberdayaan Masyarakat (PSP2M) Universitas Brawijaya Malang. Melalui acara ini, diharapkan mahasiswa dapat memberikan manfaat bagi guru dalam rangka menghadapi perubahan pola pembelajaran.

Coaching online yang di ajarkan kepada guru sekolah dasar berupa aplikasi Zoom, Google Meet, Google Classroom, Google Form, Powtoon, VideoShow, dan WhatsApp Group. Berikut ulasan mendetail terkait Coaching Online yang diselenggarakan oleh Tim Transformasi pendidikan yang diberikan untuk Guru Sekolah Dasar: 


\begin{tabular}{|l|l|l|}
\hline $\begin{array}{c}\text { Tanggal Penyelenggaraan acara } \\
\text { Coaching Online }\end{array}$ & \multicolumn{1}{|c|}{ Topik } & \multicolumn{1}{c|}{ Materi yang diajarkan } \\
\hline 22 Juni 2020 & Zoom \& Google Meet & $\begin{array}{l}\text { Mempelajari penggunaan aplikasi } \\
\text { zoom dan Google Meet sebagai } \\
\text { media tatap muka daring dengan } \\
\text { siswa. }\end{array}$ \\
\hline 23 Juni 2020 & Google Classroom \& & $\begin{array}{l}\text { Mempelajari penggunaan aplikasi } \\
\text { google classroom dan Google Form } \\
\text { sebagai media pembelajaran dan } \\
\text { pembuatan soal ujian. }\end{array}$ \\
\hline 24 Juni 2020 & Poogle Form & $\begin{array}{l}\text { Mempelajari penggunaan aplikasi } \\
\text { powtoon sebagai media untuk } \\
\text { membuatan video pembelajaran } \\
\text { yang menarik. }\end{array}$ \\
\hline 26 Juni 2020 2020 & Editing Video Dasar & $\begin{array}{l}\text { Mempelajari aplikasi untuk } \\
\text { mengedit video pembelajaran. }\end{array}$ \\
\hline & Whatsapp Group & $\begin{array}{l}\text { Mempelajari penggunaan aplikasi } \\
\text { Whatsapp Group yang dapat } \\
\text { digunakan untuk berkomunikasi } \\
\text { dengan siswa. }\end{array}$ \\
\hline
\end{tabular}

Pasca pelatihan peserta diberikan video tutorial untuk mengulang materi yang telah diajarkan selama acara Coaching Online. Video tutorial tersebut dapat dilihat pada channel YouTube Pusat Studi Pesantren dan Pemberdayaan Masayarakat Universitas Brawijaya. Video tutorial tersebut berisi cara penggunaan aplikasi dan menjelaskan fitur-fitur yang tersedia pada aplikasi.

\section{Kesimpulan}

Coaching Online merupakan salah satu solusi untuk membantu guru dalam menggunakan aplikasi yang bisa digunakan untuk menunjang Kegiatan Belajar Mengajar (KBM). Coaching Online dilaksanakan pada tanggal 22 Juni 2020-27 Juni 2020 dengan menggunakan Zoom. Coaching online yang di ajarkan berupa aplikasi Zoom, Google Meet, Google Classroom, Google Form, Powtoon, VideoShow, dan WhatsApp Group. Pasca pelatihan peserta diberikan video tutorial. Video tutorial tersebut dapat dilihat pada channel YouTube Pusat Studi Pesantren dan Pemberdayaan Masayarakat Universitas Brawijaya.
Selain diberikan video tutorial, peserta juga diberikan tugas untuk membuat luaran hasil dari Coaching Online yang didapatkan oleh peserta. Tugas tersebut dapat berupa karya yang wajib dihasilkan oleh peserta seperti misalnya pembuatan soal ujian yang dibuat dengan google form, video tutorial pembelajaran atau video animasi yang dibuat oleh peserta hasil dari pembelajaran yang diperoleh selama acara Coaching Online.

\section{Ucapan Terima Kasih}

Saya menyampaikan ucapan terima kasih kepada Pusat Studi Pesantren Universitas Brawijaya yang telah memfasilitasi studi ini.

\section{Daftar Pustaka}

CNN Indonesia. (2020). Kemendikbud: Tahun Ajaran Baru Tak Mundur, Tetap 13 Juli 2020. Diakses pada : https://www.cnn indonesia.com/nasional/2020060911282420-511320/kemendikbud-tahun-ajaran-baru -tak-mundur-tetap-13-juli-2020, pada tanggal: 19 Oktober 2020, pukul: 20.29 
Bona, M. (2020). Hanya 8\% Guru yang Paham Gawai untuk Pembelajaran Daring Diakses pada: https://www.beritasatu.com/elviraanna-siahaan/nasional/626343/hanya-8guru-yang-paham-gawai-untuk-pembelajar an-daring, pada tanggal: 19 Oktober 2020, pukul: 19.08

Kamber D. (2000). Action Learning Research Improving the Quality of Teaching and Learning. London: Page Limited 